\title{
Transfer of nodularin to the copepod Eurytemora affinis through the microbial food web
}

\author{
S. Sopanen ${ }^{1, *}$, P. Uronen ${ }^{2}$, P. Kuuppo ${ }^{1}$, C. Svensen ${ }^{3}$, A. Rühl ${ }^{4}$, T. Tamminen ${ }^{1}$, \\ E. Granéli ${ }^{5}$, C. Legrand ${ }^{5}$ \\ ${ }^{1}$ Finnish Environment Institute, PO Box 140, 00251 Helsinki, Finland \\ ${ }^{2}$ Tvärminne Zoological Station, University of Helsinki, J. A. Palménintie 260, 10900 Hanko, Finland \\ ${ }^{3}$ Norwegian College of Fishery Science, University of Tromsø, 9037 Tromsø, Norway \\ ${ }^{4}$ Department of Food Chemistry, Institute of Nutrition, University of Jena, Dornburger Strasse 25, 07743 Jena, Germany \\ ${ }^{5}$ School of Pure and Applied Natural Sciences, Marine Science Division, University of Kalmar, 39182 Kalmar, Sweden
}

\begin{abstract}
Nodularia spumigena Mertens ex Bornet \& Flahault 1886 (Cyanophyceae) frequently forms harmful blooms in the Baltic Sea, and the toxin nodularin has been found in calanoid copepods during the blooms. Although nodularin has been found at higher trophic levels of the food web, no available information exists about the role of the microbial loop in the transfer of nodularin. We followed the transfer of nodularin to the copepod Eurytemora affinis during conditions that resembled initial 'pre-bloom' (Expt 1) and late stationary (Expt 2) phases of a N. spumigena bloom. The experiments were carried out using natural plankton communities spiked with cultured $N$. spumigena and grown in laboratory mesocosms, and E. affinis, which were isolated from the Baltic Sea and had no prior contact with nodularin. The plankton community was divided into 6 size fractions as follows: $<150,<45,<20,<10,<3$ and $<0.2 \mu \mathrm{m}$, in which $E$. affinis was incubated for $24 \mathrm{~h}$. Ingestion and clearance rates, food selection and faecal pellet production were based on microscopical analyses. Nodularin was measured with HPLC-MS with electrospray ionization in the copepods, as well as in dissolved and particulate fractions before and after incubation. We found that nodularin accumulated in copepods in all the plankton size fractions. The copepods contained nodularin concentrations of $14.3 \pm 11.6\left(\right.$ mean $\pm \mathrm{SD}$ ) and $6.6 \pm 0.7 \mathrm{pg}$ ind. $^{-1}$ after incubation in the $<150 \mu \mathrm{m}$ fraction in Expt 1 and Expt 2, respectively, while the range in the smaller size fractions was from $1.3 \pm 2.8$ to $5.7 \pm 1.3 \mathrm{pg}$ ind. ${ }^{-1}$. Nodularin was transferred to the copepods through 3 pathways: (1) by grazing on filaments of small N. spumigena, (2) directly from the dissolved pool, and (3) through the microbial food web by copepods grazing on ciliates, dinoflagellates and heterotrophic nanoflagellates. The relative importance of direct grazing on small $N$. spumigena filaments varied from moderate to insignificant. The microbial loop was important in nodularin transfer to higher trophic levels. Our results suggest that the importance of the microbial loop in harmful algal bloom (HAB) toxin transfer may be underestimated both in marine and freshwater systems.
\end{abstract}

KEY WORDS: Nodularia spumigena · Nodularin · Toxin transfer · Microbial loop · Harmful algal bloom $\cdot$ Copepod $\cdot$ Eurytemora affinis

\section{INTRODUCTION}

Extensive late-summer cyanobacterial blooms dominated by the nitrogen-fixing filamentous species Nodularia spumigena and Aphanizomenon flos-aquae are common in the brackish Baltic Sea (Kahru et al.
1994). N. spumigena is a harmful species due to its ability to produce nodularin, a hepatotoxic cyclic pentapeptide (Sivonen et al. 1989). Nodularin has been identified as an inhibitor of protein phosphatases 1 and 2A (Yoshizawa et al. 1990) and a potent tumor promoter (Nishiwaki-Matsushima et al. 1992). Cyanobacterial 
toxins are usually intracellular during exponential growth, but are released into the water when the bloom decays (Lehtimäki et al. 1997). Nodularin is a stable molecule; i.e. nodularin levels can stay constant for at least $40 \mathrm{~d}$ in sterile seawater, but in non-sterile conditions degradation is faster (Hagström 2006).

Copepods are able to graze on Nodularia spumigena (Sellner et al. 1994, Koski et al. 1999, KozlowskySuzuki et al. 2003). As a result, nodularin is incorporated into their body tissues (Kozlowsky-Suzuki et al. 2003, Karjalainen et al. 2006) and partly transferred to the faecal pellets (Lehtiniemi et al. 2002). From the copepods, nodularin can be transferred through the aquatic food web, as demonstrated in mysids (Engström-Öst et al. 2002b) and fish (Sipiä et al. 2007).

Although copepods can acquire nodularin by direct grazing on Nodularia spumigena filaments, other pathways are also possible. Karjalainen et al. (2003) suggested that copepods may obtain dissolved nodularin directly from the water or via ciliates, which in turn are able to take up dissolved nodularin. However, the role of the microbial loop (bacteria, heterotrophic nanoflagellates) in the nodularin transfer is still unclear. The microbial loop is generally an important link in the transfer of dissolved organic matter from bacteria via bacterivore flagellates and ciliates to crustacean zooplankton (Azam et al. 1983, Kuuppo-Leinikki et al. 1994). During the Baltic cyanobacterial bloom, bacterial production increases significantly (Kuosa \& Kivi 1989) and the bacteria are actively grazed by heterotrophic flagellates and small ciliates (Kuuppo-Leinikki 1990, Sellner 1997). Ciliates, in turn, are further controlled by copepods. Thus, a bloom of filamentous cyanobacteria forms a rich planktonic community of alternative food for grazers (Engström-Öst et al. 2002a), and within that community nodularin can serve as a source of dissolved organic carbon for bacteria.

Our experiments were designed to follow the transfer of nodularin to the copepod Eurytemora affinis during stationary and decaying phases of a cyanobacterial bloom. E. affinis is an important grazer of the summer plankton community in the Gulf of Finland, Baltic Sea, and is, to some extent, able to graze on filamentous cyanobacteria. We tested 3 potential pathways of nodularin transfer to the copepods: (1) directly by grazing on Nodularia spumigena filaments; (2) directly from the dissolved pool; and (3) through grazing on the components of the microbial food web.

\section{MATERIALS AND METHODS}

Mesocosm set-up. A natural late-summer plankton community sample was collected from the surface layer on 29 July 2002, approximately $1 \mathrm{~km}$ off the northeastern shore of the large island of Öland in the Baltic Sea. The seawater was immediately filtered through a $150 \mu \mathrm{m}$ nylon net to eliminate most of the metazoan grazers. During the same day, the seawater was transferred into 3001 cylinders (indoor mesocosms) at the laboratory of the University of Kalmar. The mesocosms were kept at in situ temperature $\left(18^{\circ} \mathrm{C}\right)$ and under controlled light $(150 \mu \mathrm{mol}$ photons $\mathrm{m}^{-2} \mathrm{~s}^{-1}$ at $16: 8 \mathrm{~h}$ light:dark) conditions during the experiments. Nutrients were added daily to the mesocosms (0.8 to $1.6 \mu \mathrm{M} \mathrm{NO}_{3}$ and $0.1 \mu \mathrm{M} \mathrm{PO}_{4}$ in N/P-bal-

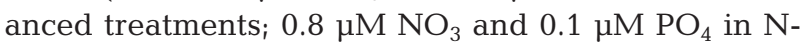
deficient treatments). Iron, other metals and vitamins were added daily corresponding to $f / 20$ (1/20 of f medium) (Guillard \& Ryther 1962). All treatments were done in triplicate. The experiment was run for $12 \mathrm{~d}$ and the mesocosms were manually stirred daily. Since microscopic observations revealed that Nodularia spumigena was undetectable in the natural seawater, the mesocosms were inoculated with cultured N. spumigena (KAC 13, Kalmar Algal Collection, University of Kalmar) at $5 \mu \mathrm{g}$ chlorophyll a ( $\mathrm{chl}$ a) $\mathrm{l}^{-1}$ final concentration. Blooms of cyanobacteria developed in all mesocosms after $5 \mathrm{~d}$ of nutrient additions (4 August). The first grazing experiment (Expt 1) starting on 4 August was done with water collected from N/Pbalanced mesocosms and represented initial or 'prebloom' conditions with low chl a $\left(1.3 \mu \mathrm{g} \mathrm{l^{-1 }}\right)$. In the second experiment (Expt 2) starting on 7 August, the experimental water was taken from a $\mathrm{N}$-deficient mesocosm and represented stationary conditions with high chl a $\left(9.4 \mu \mathrm{g} \mathrm{l}^{-1}\right)$ and decaying filaments of $N$. spumigena. However, because of the internal nutrients, our experimental design may not adequately mimic a system in stationary phase, but rather under unbalanced nutrient input.

Cultivation and handling of Eurytemora affinis. Adult E. affinis females were allowed to feed on sizefractionated microbial communities taken from the mesocosms, after which nodularin concentrations were measured and grazing and food preferences compared. To avoid background levels of nodularin, we used 'clean' E. affinis copepods from the northern Baltic Sea, which had been cultured in batches for 3 generations. Batch cultures were initiated from newly hatched nauplii. The copepods were grown with a mixed diet of Rhodomonas salina and Brachiomonas sp. (>400 $\mu \mathrm{g} \mathrm{C}^{-1}$ ) at Tvärminne Zoological Station, Finland, and they had never been in contact with Nodularia spumigena. The culture conditions (temperature $=18^{\circ} \mathrm{C}$; salinity $=6$ PSU) were similar to experimental conditions. For the experiments, adult females were picked and transferred into nodularin-free GF/F filtered seawater for 6 to $10 \mathrm{~h}$ to allow their guts to clear previously ingested food. 
Nodularin transfer experiments. For the nodularin transfer experiments, the water containing the $<150 \mu \mathrm{m}$ plankton community was taken from mesocosms. In Expt 1, the $<150 \mu \mathrm{m}$ plankton community taken from N/Pbalanced mesocosms was further divided into $<45$ (45 to 20) $\mu \mathrm{m},<20$ (20 to 10$) \mu \mathrm{m},<10$ (10 to 3 ) $\mu \mathrm{m},<3$ (3 to 0.2 ) $\mu \mathrm{m}$ and $<0.2 \mu \mathrm{m}$ size fractions before the addition of copepods. The $<150 \mu \mathrm{m}$ fraction was regarded as the 'total' community. The $<45 \mu \mathrm{m}$ fraction was prepared by inverse filtration, which is a method assumed to minimize cell breakage and, thus, also minimize leakage of dissolved matter. The $<20$ and $<10 \mu \mathrm{m}$ size fractions were further prepared from the $<45 \mu \mathrm{m}$ fraction by inverse filtration through a 20 or $10 \mu \mathrm{m}$ mesh net, respectively. The 2 smallest size fractions $(<3 \mu \mathrm{m}$ and $<0.2 \mu \mathrm{m})$ were prepared by filtering the $<10 \mu \mathrm{m}$ water through either a $3 \mu \mathrm{m}$ polycarbonate filter (Poretics) or a $0.2 \mu \mathrm{m}$ size Sartorius cartridge using as gentle a vacuum pressure as possible ( $\leq 0.1$ bar). In Expt 2, the water for the experiment was taken from Ndeficient mesocosms. Preparation of the plankton size fractions for Expt 2 was done in the same way except that the $<20 \mu \mathrm{m}$ size fraction was not prepared.

The experiments were carried out in $1.1 \mathrm{l}$ acidwashed glass bottles, using 5 replicates and 2 controls for each plankton size fraction. Each experimental bottle received 35 Eurytemora affinis females (ca. 1:1 ratio of ovigerous and non-ovigerous females), while the controls were left without copepods. The bottles were placed in a plankton wheel rotating at a speed of $0.5 \mathrm{rpm}$ in dim light at $18^{\circ} \mathrm{C}$. After $24 \mathrm{~h}$ incubation, the copepods from each experimental bottle were collected onto a $200 \mu \mathrm{m}$ sieve and their survival was checked by viewing under a microscope. For nodularin analysis the copepods were flushed individually 4 times with GF/F filtered seawater and placed into microfuge tubes. In Expt 2, samples were prepared in the same way except that Milli-Q water was used instead of filtered seawater to avoid salt crystals in the samples. The copepods were dried with a Speed Vac freeze-dryer. The copepods from Expt 1 were carefully separated from the salt crystals under a stereo microscope after the freeze-drying. All the freeze-dried animals were stored at $-18^{\circ} \mathrm{C}$ until nodularin analyses (maximum storage $=21 \mathrm{~d}$ ).

Plankton sampling, identification and quantification. To identify and enumerate the plankton species, one initial sample from each size fraction was taken. After the $24 \mathrm{~h}$ incubation period, subsamples were taken from all replicate and control bottles in each plankton size fractions. For pico- and nanoplankton counts, a $20 \mathrm{ml}$ sample was fixed with unbuffered $<0.2 \mu \mathrm{m}$ filtered glutaraldehyde (final conc. 1\%), stained with proflavine (flagellates and picocyanobacteria) or DAPI (heterotrophic bacteria), filtered onto $0.2 \mu \mathrm{m}$ polycarbonate filters (Poretics) and frozen (Porter \& Feig 1980,
Kuuppo-Leinikki \& Kuosa 1989, Turley 1993). For microplankton and cyanobacterial counts, a $50 \mathrm{ml}$ sample was fixed with acid Lugol's solution.

Pico- and nanoplankton in the plankton fractions were counted with an epifluorescence microscope (Olympus DP50 or Leitz Diaplan) using 500× and 1250× magnifications. The proflavine and DAPI stained samples were counted under blue and ultraviolet excitation wavelengths, respectively. At least 50 microscopical fields were counted from each filter. Larger phytoplankton, filamentous cyanobacteria and ciliates were identified and counted from the Lugol preserved samples (3 replicates and both controls) with an inverted microscope (Zeiss) with 205x and 806× magnifications following the method of Utermöhl (1958). Both phytoplankton and protists were grouped in the subsequent grazing and preference analyses (see text in Table 2 legend).

Heterotrophic nanoflagellates (HNF) were classified into 3 size categories, based on their cell length, by means of an ocular micrometer. In each size category, the biovolume was estimated using the formula of an ellipsoid with a flattened round bottom. Phototrophic nanoflagellates (PNF) were distinguished by their cell shape and red chlorophyll or orange phycoerythrin (cryptomonads) fluorescence, and their biovolumes were calculated from cell dimensions with speciesspecific formulas (Edler 1979). The picoplankton cell numbers were converted to carbon using average volumes and carbon conversion factors, respectively, as

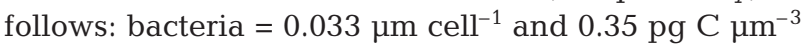
(Bjørnsen 1986), picocyanobacteria $=0.51 \mu \mathrm{m} \mathrm{cell}{ }^{-1}$ and $0.22 \mathrm{pg} \mathrm{C} \mathrm{mm}^{-3}$ (Børsheim \& Bratbak 1987). For other biomasses the following carbon conversion factors were used: dinoflagellates, pg C cell ${ }^{-1}=0.760 \times$ volume $^{0.819}$ (Menden-Deuer \& Lessard 2000); other algal groups, $0.11 \mathrm{pg} \mathrm{C} \mathrm{mm}^{-3}$ (Edler 1979); and ciliates, 0.19 pg C $\mu^{-3}$ (Putt \& Stoecker 1989).

Feeding parameters. Clearance and ingestion rates were calculated according to Frost (1972) by comparing the disappearance of the food cells from the experimental bottles containing copepods with that in the control bottles without copepods. Weight-specific ingestion was calculated using the carbon content of

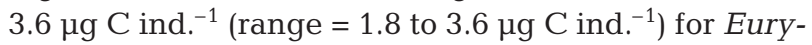
temora affinis, which had earlier been measured in the area during July (Koski 1999). We have not corrected our feeding rates to take into account possible trophic cascade effects. Microzooplankton, including ciliates and nauplii, are able to graze flagellates in the control treatments without copepods. This background grazing may decrease the growth rates of flagellates and in this way influence the observed clearance and ingestion rates on these groups. Thus, these values must be seen as relative indicators of grazing. The Chesson 
selection index $\alpha$ was used to evaluate the food selection and estimated as the ratio of the grazed units in the diet to the availability of particular food in the incubation bottles (Chesson 1983). Ten plankton groups (see text in Table 2 legend) were used in the analyses, while bacteria and picocyanobacteria were excluded. The index $\alpha$ varies between 0 and 1. A particular food type is neither selected nor avoided (i.e. food type is grazed proportionally to its availability) if $\alpha=\mathrm{m}^{-1}$ ( $\mathrm{m}=$ number of food types available). When $\alpha>\mathrm{m}^{-1}$ the food type is selected, and when $\alpha<\mathrm{m}^{-1}$ the selection is negative.

A $100 \mathrm{ml}$ subsample of each replicate was preserved with acid Lugol's solution ( $2 \%$ final concentration) to be used to count faecal pellets. The samples were settled for $24 \mathrm{~h}$ according to Utermöhl (1958) and the pellets were counted at 100× magnification using an inverted microscope. The volume of faecal pellets was estimated by measuring the length and width of all pellets found. Their carbon content was calculated using the conversion factor of $0.057 \times 10^{-9} \mathrm{mg} \mathrm{C} \mathrm{m}^{-3}$ (González et al. 1994).

Nodularin analyses. For particulate nodularin analyses, $500 \mathrm{ml}$ aliquots from the $<150,<45,<20,<10$, and $<3 \mu \mathrm{m}$ size fractions were taken both before and at the end of the experiments. The samples were filtered onto glass fibre filters (GF/F, Whatman) and stored frozen until nodularin analysis $\left(-18^{\circ} \mathrm{C}\right.$, maximum storage $=$ $21 \mathrm{~d}$ ). Dissolved nodularin was measured from the $<0.2$ and $<3 \mu \mathrm{m}$ size fractions in Expt 1 and from the $<0.2$, $<3$ and $<150 \mu \mathrm{m}$ size fractions in Expt 2 . For the analysis, a $500 \mathrm{ml}$ water sample was taken and stored at $6^{\circ} \mathrm{C}$. The initial concentrations of dissolved nodularin were measured directly from the mesocosms. Plastic laboratory materials were avoided whenever possible to minimize the risk of nodularin loss through hydrophobic behaviour (Hyenstrand et al. 2001).

The dissolved nodularin, as well as nodularin in particulate form and in the copepods was analyzed with HPLC-MS with electrospray ionization (LC-ESI-MS) according to Dahlmann et al. (2003). Before LC-ESIMS measurements, particulate material filtered on glass fibre filters or dehydrogenated copepod biomass were extracted using 1:1 methanol:water (v/v) solution supported by ultrasound. Depending on the amount of sample material, between 0.5 and $3 \mathrm{ml}$ of the methanol:water mixture was applied. After centrifugation $(10 \mathrm{~min}$ at $22000 \times g)$ the supernatant was filtered (nylon filter, $0.2 \mu \mathrm{m}$ mesh size). The extracts were directly injected for LC-ESI-MS analysis. Samples for dissolved nodularin analysis were prepared according to ISO 20179:2005 (Water quality-Determination of microcystins-Method using solid phase extraction [SPE] and HPLC with UV detection). In this protocol, the water samples (dissolved nodularin) were enriched on a C18 cartridge (500 mg, Bakerbond). The eluate was then evaporated under nitrogen and injected for LC-ESI-MS analysis after reconstitution.

The samples were analyzed by LC-ESI-MS (Perkin Elmer series 200 autosampler and pump coupled to an Applied Biosystems API 165 mass spectrometer). The chromatographic separation was carried out on a reversed phase Aqua column $(5 \mathrm{~mm} \mathrm{C} 18,250 \times$ $4.60 \mathrm{~mm}$ inside diameter, Phenomenex) by application of acetonitrile and $0.01 \mathrm{M}$ trifluoroacetic acid (TFA) with $0.1 \%$ heptafluorobutyric acid (HFBA) as eluents in gradient mode (Table 1). The mass spectrometer was operated in selective ion monitoring mode using positive ionization of nodularin, detected as $[\mathrm{M}+\mathrm{H}]+$ ion at $\mathrm{m} / \mathrm{z}$ 828.5. Nodularin standard was run both for identification purposes and for quantification, which was performed using peak areas.

Statistical analyses. To identify which groups were grazed by the copepods, the calculated clearance rates were analysed statistically using 1-way ANOVA or the Kruskal-Wallis 1-way ANOVA if the data did not fulfill the criteria of parametric testing. The StudentNewman-Keuls (SNK) method was used as a post hoc test. After calculating the Chesson selection index $\alpha$, we used Dunnett's method to distinguish those food groups that were significantly preferred in the copepods' diet. Linear regression was performed to examine which variables explained variances in nodularin content of the copepods.

\section{RESULTS}

\section{Initial conditions}

Biomass and community structure in different size fractions

The pre-filtration produced relatively different planktonic communities in the size fractions in terms of both total biomass and species composition (Table 2).

Table 1. Gradient for liquid chromatography elution. TFA: trifluoroacetic acid; HFBA: heptafluorobutyric acid

\begin{tabular}{|lcc|}
\hline $\begin{array}{c}\text { Time } \\
(\text { min) }\end{array}$ & $\begin{array}{c}\text { Eluent A: } \\
\text { acetonitrile } \\
(\%)\end{array}$ & $\begin{array}{c}\text { Eluent B: } \\
\text { aqueous 0.01 M TFA } \\
\text { containing 0.1 \% HFBA } \\
(\%)\end{array}$ \\
\hline 0 & 5 & 95 \\
$0-12$ & 40 & 60 \\
$12-17$ & 70 & 30 \\
$17-27$ & 70 & 30 \\
$27-28$ & 5 & 95 \\
$28-36$ & 5 & 95 \\
\hline
\end{tabular}


Table 2. Initial biomass $\left(\mu \mathrm{g} \mathrm{C}^{-1}\right)$ and proportion of total (\%) of different species or taxonomic groups in plankton size fractions. The phytoplankton community was grouped as follows: Nodularia spumigena (in Expt 1: N. spumigena small and natural, in Expt 2: natural N. spumigena); other cyanobacteria (Snowella spp., Pseudanabaena spp., Anabaena spp., Aphanizomenon flosaquae); diatoms (Bacillariales spp., Chaetoceros spp., Cylindrotheca sp., Nitzschia spp., Skeletonema costatum); Dinoflagellates (Amphidinium sp., Gymnodinium spp., Dinophyceae spp.); small ciliates $(<23 \mu \mathrm{m}$, Myrionecta rubra, Mesodinium spp., Lohmaniella oviformis, Ascenasia sp., Urotricha sp.); large ciliates (>23 $\mu \mathrm{m}$, Euplotes sp., Cothurnia maritima, Helicostomella sp., Strombidium spp., Strobilidium spp.); other heterotrophs (unidentified heterotrophs); other autotrophs (Oocystis spp., Eutreptiella sp. Planktonema lauterbornii, Cryptomonas spp. $>10 \mu \mathrm{m})$; HNF heterotrophic nanoflagellates; PNF phototrophic nanoflagellates (Pyramimonas sp., Cryptomonas sp. $<10 \mu \mathrm{m}$, Chrysochromulina spp., Chaetoceros throndsenii, pikoeukaryotes); PICO (picocyanobacteria); bacteria

\begin{tabular}{|c|c|c|c|c|c|c|}
\hline \multirow{3}{*}{ Expt 1} & \multicolumn{6}{|c|}{ Biomass $\left(\mu \mathrm{C} \mathrm{Cl}^{-1}\right)$ and proportion $(\%$, in parentheses) of different species or taxonomic groups } \\
\hline & $<150 \mu \mathrm{m}$ & $<45 \mu \mathrm{m}$ & $<20 \mu \mathrm{m}$ & $<10 \mu \mathrm{m}$ & $<3 \mu \mathrm{m}$ & $<0.2 \mu \mathrm{m}$ \\
\hline & & & & & & \\
\hline Nodularia spumigena & $27(6)$ & $13(3)$ & $20(5)$ & $5(2)$ & & \\
\hline Other cyanobacteria & $8(2)$ & $6(2)$ & $3(1)$ & $3(1)$ & & \\
\hline Diatoms & $9(2)$ & $6(2)$ & $3(1)$ & $4.5(2)$ & & \\
\hline Dinoflagellates & $145(30)$ & $47(12)$ & $57(14)$ & $40(12)$ & & \\
\hline Small ciliates & $60(12)$ & $78(20)$ & 76 (19) & 53(16) & & \\
\hline Large ciliates & $7(1)$ & $11(3)$ & $6(1)$ & $1(0.3)$ & & \\
\hline Other heterotrophs & $3(1)$ & $7(2)$ & $5(1)$ & $2(1)$ & & \\
\hline Other autotrophs & 7 (1) & 5 (1) & $4(1)$ & $4(1)$ & & \\
\hline HNF & $3(1)$ & $2(1)$ & $2(0.5)$ & 3 (1) & $2(1)$ & \\
\hline PNF & $13(3)$ & $17(4)$ & $17(4)$ & $17(5)$ & $8(4)$ & \\
\hline PICO & 106(22) & $103(26)$ & $114(28)$ & $94(28)$ & $56(29)$ & $0.1(0.3)$ \\
\hline Bacteria & $101(21)$ & $98(25)$ & $98(24)$ & $106(32)$ & $124(65)$ & $32(99.7)$ \\
\hline Total & 489 & 394 & 405 & 331 & 190 & 32.1 \\
\hline Expt 2 & & & & & & \\
\hline Nodularia spumigena & $109(16)$ & $2(0.4)$ & & & & \\
\hline Other cyanobacteria & $12(2)$ & $13(2)$ & & $7(2)$ & & \\
\hline Diatoms & $21(3)$ & $12(2)$ & & $4(1)$ & & \\
\hline Dinoflagellates & $166(24)$ & $194(35)$ & & $108(24)$ & & \\
\hline Small ciliates & $34(5)$ & $20(4)$ & & $21(5)$ & & \\
\hline Large ciliates & $21(3)$ & $14(3)$ & & $5(1)$ & & \\
\hline Other heterotrophs & $27(4)$ & $16(3)$ & & $16(4)$ & & \\
\hline Other autotrophs & $6(1)$ & $4(1)$ & & $4(1)$ & & \\
\hline $\mathrm{HNF}$ & $6(1)$ & $9(2)$ & & $4(1)$ & $2(1)$ & \\
\hline PNF & $57(8)$ & $46(8)$ & & $42(9)$ & $27(18)$ & \\
\hline PICO & $110(16)$ & 104 (19) & & $102(23)$ & $5(3)$ & $0.04(0.3)$ \\
\hline Bacteria & $111(16)$ & $115(21)$ & & $130(29)$ & $114(77)$ & $15(99.7)$ \\
\hline Total & 680 & 549 & & 443 & 148 & 15.04 \\
\hline
\end{tabular}

The initial total biomass was 489 and $680 \mu \mathrm{g} \mathrm{Cl}^{-1}$ in the $<150 \mu \mathrm{m}$ size fraction (the community from the mesocosm) in Expt 1 and Expt 2, respectively (Table 2), of which the biomass of Nodularia spumigena was $6 \%$ $\left(27 \mu \mathrm{C} \mathrm{C}^{-1}\right)$ and $16 \%\left(109 \mu \mathrm{g} \mathrm{C}^{-1}\right)$, respectively. Due to the addition of cultured $N$. spumigena in Expt 1, 2 types of filaments were present in the samples: longchained filaments, with cell size 3.5 to $6 \mu \mathrm{m} \times 10$ to $13 \mu \mathrm{m}$, and a short morphotype, with cell size 2 to $4 \mu \mathrm{m}$ $\times 4$ to $5 \mu \mathrm{m}$. In this paper, we refer to the long-chained form as 'natural' N. spumigena, and the small morphotype as 'small' N. spumigena.

In the $<150 \mu \mathrm{m}$ size fraction, ciliates and dinoflagellates were important groups and their proportion of the total initial biomass was 13 and $30 \%$ in Expt 1, and 8 and $24 \%$ in Expt 2 (Table 2), respectively. The initial biomass of PNF was low $\left(13 \mu \mathrm{g} \mathrm{C}^{-1}\right)$ in Expt 1 com- pared with Expt 2 where their biomass was ca. 4-fold higher. The initial biomass of HNF was low (from 3 to

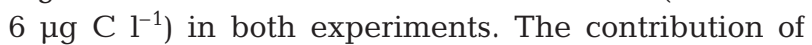
bacteria to the total biomass was moderate (from 100 to $111 \mu \mathrm{g} \mathrm{C}^{-1}$ ) in both experiments (Table 2).

In Expt 1, small Nodularia spumigena could be filtered into $<45,<20$ and $<10 \mu \mathrm{m}$ fractions (Table 2 ), but in Expt 2 only few small pieces of natural N. spumigena filaments in the $<45 \mu \mathrm{m}$ fraction were found. For other plankton groups, the result of fractionation was similar in both experiments. The $<45,<20$ and $<10 \mu \mathrm{m}$ fractions contained the smallest dinoflagellates, a few large ciliates, small ciliates, small diatoms as well as the HNF and PNF. The $<3 \mu \mathrm{m}$ fraction was dominated by bacteria, which contributed to 65 and $77 \%$ of the total biomass in Expt 1 and Expt 2, respectively. The contribution of HNF and PNF to the $<3 \mu \mathrm{m}$ fraction bio- 
mass in both experiments was low (1 to $18 \%$ ). In the $<0.2 \mu \mathrm{m}$ fraction, the total initial biomass was low in both experiments and was composed of bacteria.

\section{Initial nodularin concentrations in different size fractions}

The initial concentrations of particulate nodularin in the $<150 \mu \mathrm{m}$ fraction were 387 and $199 \mathrm{ng} \mathrm{l^{-1 }}$ in Expt 1 and Expt 2, respectively (Fig. 1). Nodularia spumigena cells in Expt 1 contained roughly 2.2-fold more nodularin (0.0037 ng cell ${ }^{-1}$ ) compared with those in Expt 2 $\left(0.0017 \mathrm{ng} \mathrm{cell}{ }^{-1}\right)$. In Expt 1, $34 \%(<45 \mu \mathrm{m})$ to $87 \%$ $(<10 \mu \mathrm{m})$ of particulate nodularin disappeared due to the fractionation, and in Expt 2 the loss was even higher, being $>98.5 \%$ in $<45$ and $<10 \mu \mathrm{m}$ fractions (Fig. 1, black bars). In both of the experiments, the smallest size fractions $(<3$ and $<0.2 \mu \mathrm{m})$ did not contain any nodularin in particulate form. However, the initial

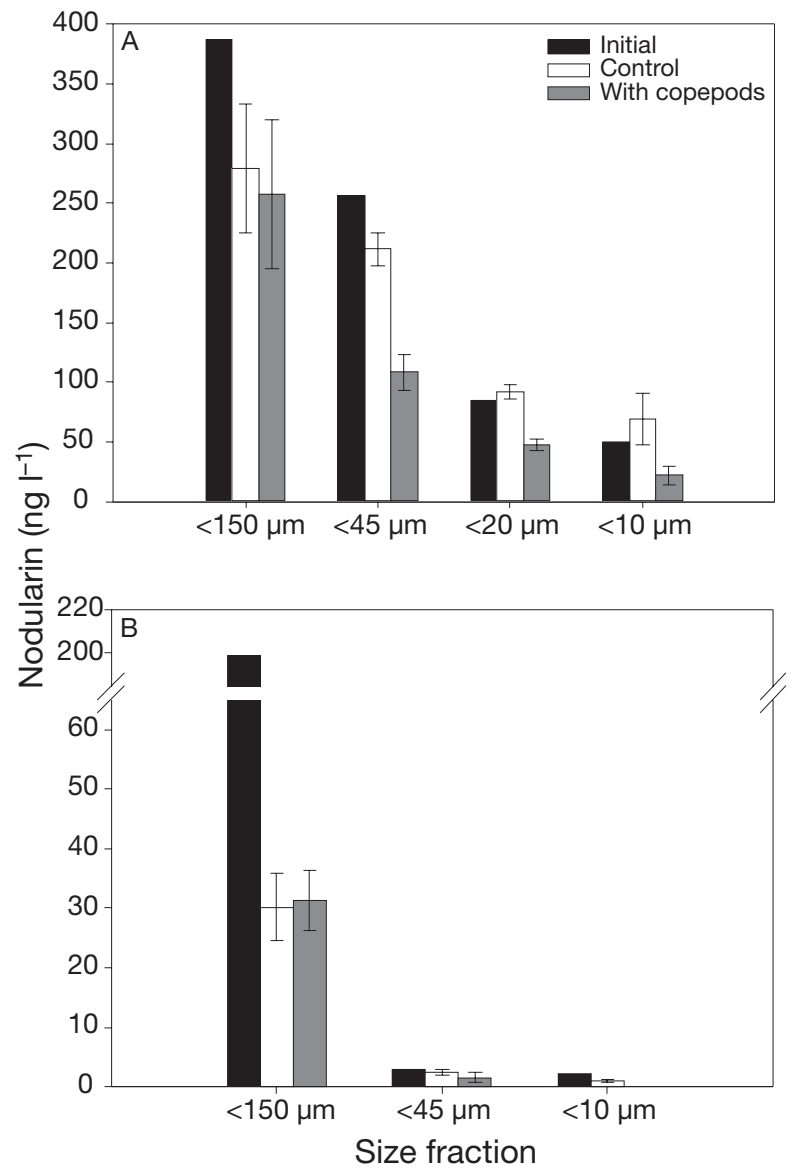

Fig. 1. Particulate nodularin concentration $\left(\mathrm{ng} \mathrm{l}^{-1}\right)$ in different size fractions at the beginning of the experiments (initial), in control treatments and in replicates with copepods after $24 \mathrm{~h}$ incubation period (average \pm SD) in (A) Expt 1 and (B) Expt 2. Note different scales on $y$-axes
Table 3. Dissolved nodularin concentrations $\left(\mathrm{ng}^{-1}\right)$ in Expt 1 and Expt 2. Initial: dissolved nodularin concentrations measured from mesocosms; With copepods: dissolved nodularin concentrations in replicates with Eurytemora affinis after $24 \mathrm{~h}$; Control: dissolved nodularin concentrations in controls without copepods after $24 \mathrm{~h}$. Data are mean $\pm \mathrm{SD}$. nd: no data

\begin{tabular}{|c|c|c|c|}
\hline & Initial & With copepods & Control \\
\hline Expt 1 & 111 & & \\
\hline$<0.2 \mu \mathrm{m}$ fraction & & $60.1 \pm 15.5$ & $32.3 \pm 6.6$ \\
\hline$<3 \mu \mathrm{m}$ fraction & & $9.0 \pm 1.1$ & nd \\
\hline Expt 2 & 41.8 & & \\
\hline$<0.2 \mu \mathrm{m}$ fraction & & $55.5 \pm 3.5$ & $53.5 \pm 2.9$ \\
\hline$<3 \mu \mathrm{m}$ fraction & & $1.3 \pm 0.2$ & $2.6 \pm 0.7$ \\
\hline$<150 \mu \mathrm{m}$ fraction & & $9.0 \pm 0.7$ & $9.4 \pm 0.3$ \\
\hline
\end{tabular}

concentration of dissolved nodularin, measured from mesocosms, was 111 and $42 \mathrm{ng} \mathrm{l}^{-1}$, which corresponded to 22 and $17 \%$ of the total nodularin in the $<150 \mu \mathrm{m}$ fraction in Expt 1 and Expt 2, respectively (Table 3).

\section{Nodularin dynamics}

How much nodularin was channelled to the copepods?

Nodularin was found in the copepods incubated in all the plankton fractions in both of the experiments. Nodularin had no direct negative effects on the copepods, and their survival rates remained above 98\% during the experiments. At the end of the experiments, the nodularin content of the copepods varied between 1.3 and $14.3 \mathrm{pg}$ ind. $^{-1}$ in Expt 1, and between 1.6 and $6.6 \mathrm{pg}$ ind. $^{-1}$ in Expt 2 (Table 4), corresponding to 0.08 to $6.5 \%$ of the initial particulate nodularin concentration in the different fractions (Table 4). From the initial dissolved nodularin pool, 0.04 to $0.3 \%$ was channelled to the copepods, as estimated by the copepods incubated in the $<0.2 \mu \mathrm{m}$ and $<3 \mu \mathrm{m}$ size fractions (Table 4 ).

\section{Nodularin in the biomass (particulate form)}

In both experiments, particulate nodularin concentrations decreased during the $24 \mathrm{~h}$ incubation (see Fig. 1A,B) in all size fractions, and it was not found in the $<3 \mu \mathrm{m}$ fractions at the end of the experiments.

The relative change in the concentration of particulate nodularin in the $<150 \mu \mathrm{m}$ fraction was equal in the replicates of both experiments with copepods and the controls (Fig. 2A,B). In the other size fractions, the particulate nodularin decreased significantly more in the replicates with copepods compared with the controls ( $t$-test, $\mathrm{p}<0.001$ for $<20$ and $<45$ fractions) (Fig. $2 \mathrm{~A}$ ). 
Table 4. Particulate and dissolved nodularin from different size fractions channelled to the copepod Eurytemora affinis during $24 \mathrm{~h}$ incubations. pg ind..$^{-1}$ : nodularin content in the copepods after $24 \mathrm{~h}$ incubation in different size fractions; \% ind. ${ }^{-1}$ : the share of the initial nodularin channelled to 1 individual; \% copepod biomass ${ }^{-1}$ : the share of the initial nodularin channelled to copepods' total biomass $(n=5$ replicate bottles with 35 copepods in each, mean \pm SD)

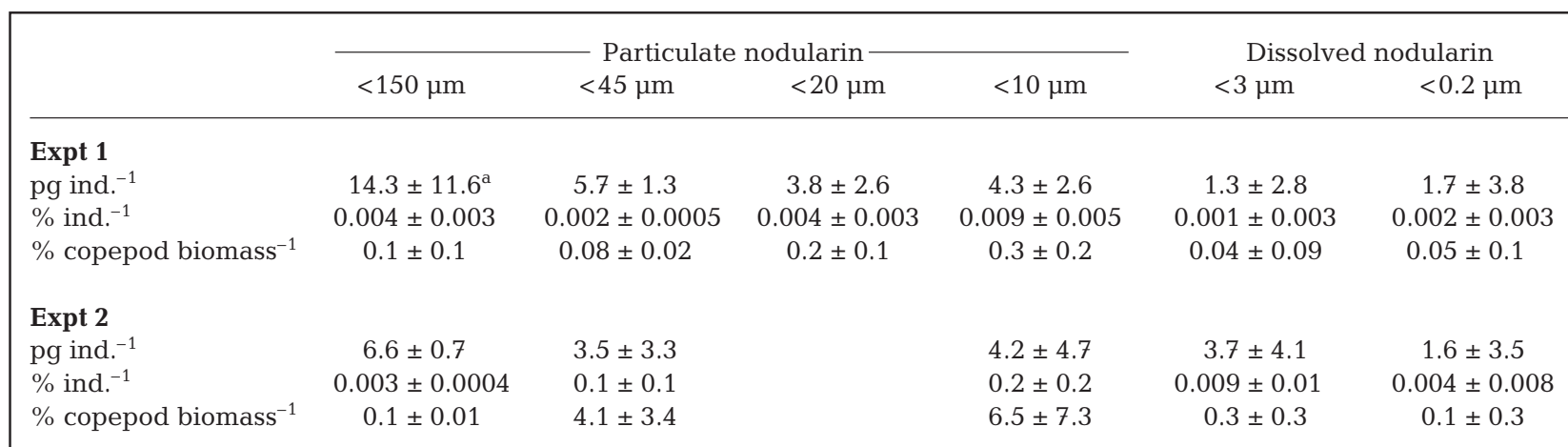

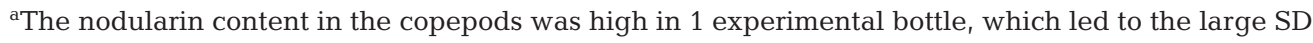

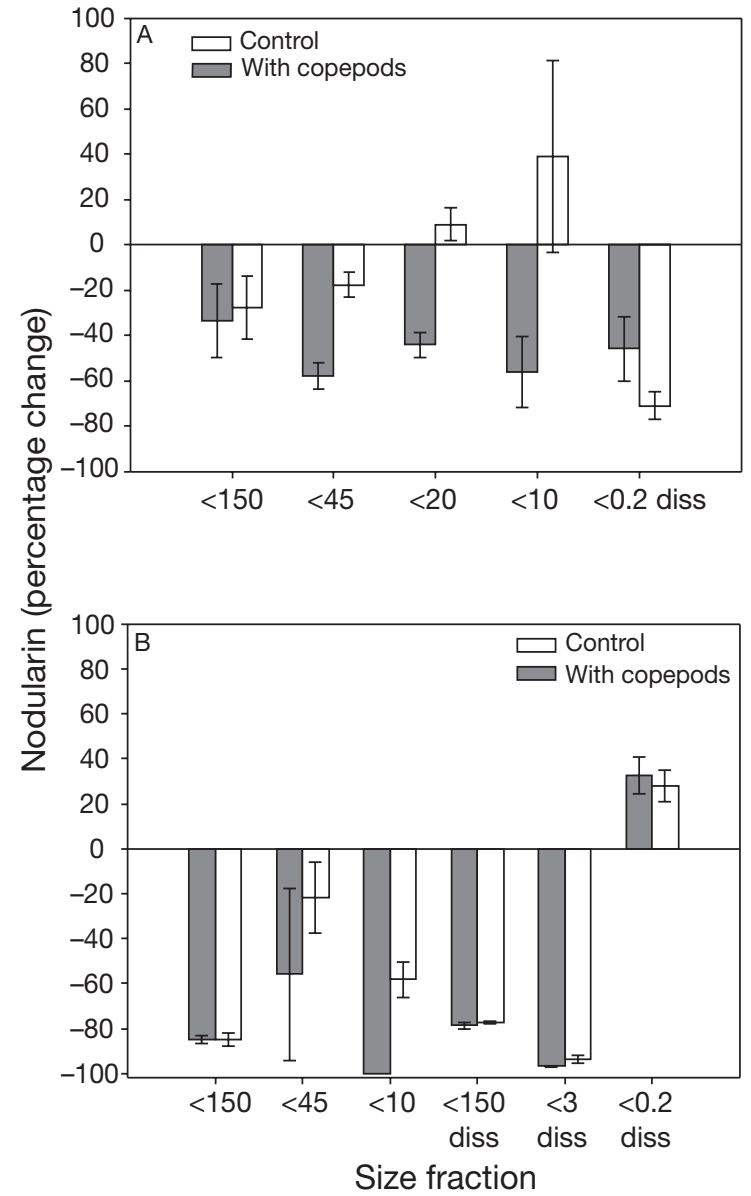

Fig. 2. Change $(\%$, average $\pm \mathrm{SD})$ of particulate and dissolved (diss) nodularin in different size fractions compared with initial in (A) Expt 1 and (B) Expt 2. Open bars represent controls and gray bars represent replicates with copepods. In Expt 2, additional measurements of dissolved nodularin were made in $<150$ and $<3 \mu \mathrm{m}$ size fractions
The concentration of nodularin that disappeared was compared with that measured from the copepods to roughly estimate what percentage of nodularin potentially was channelled to the organisms. Of the nodularin that disappeared in Expt 1, up to $0.5 \%$ (mean \pm $\mathrm{SD}=0.3 \pm 0.2 \%$ ) was found in the copepods. In Expt 2, the particulate nodularin concentrations were low after the incubation; therefore, the amounts found in the copepods corresponded to up to $57 \%(18.5 \pm 21.7 \%)$ of the nodularin that disappeared.

\section{Nodularin in the dissolved form}

The smallest size fractions $(<3 \mu \mathrm{m}$ and $<0.2 \mu \mathrm{m})$ contained nodularin only in the dissolved form (Table 3 ). After the $24 \mathrm{~h}$ incubation, dissolved nodularin concentrations in the $<0.2 \mu \mathrm{m}$ fraction decreased $25 \%$ more in the controls compared with the replicates in Expt 1 (Table 3, Fig. 2A), whereas in Expt 2, the dissolved nodularin concentrations increased in both treatments (Table 3, Fig. 2B). The dissolved nodularin concentrations in the $<3$ and $<150 \mu \mathrm{m}$ fractions were 5.5 - to 42 fold lower compared with that in the $<0.2 \mu \mathrm{m}$ fraction (Table 3). In these fractions, more than $80 \%$ of the dissolved nodularin disappeared during the $24 \mathrm{~h}$ incubation (Fig. 2B).

\section{Feeding and egestion}

\section{Expt 1}

Potential routes of the nodularin to copepods were estimated by calculating the ingestion and food selection of the copepods in different size fractions during 


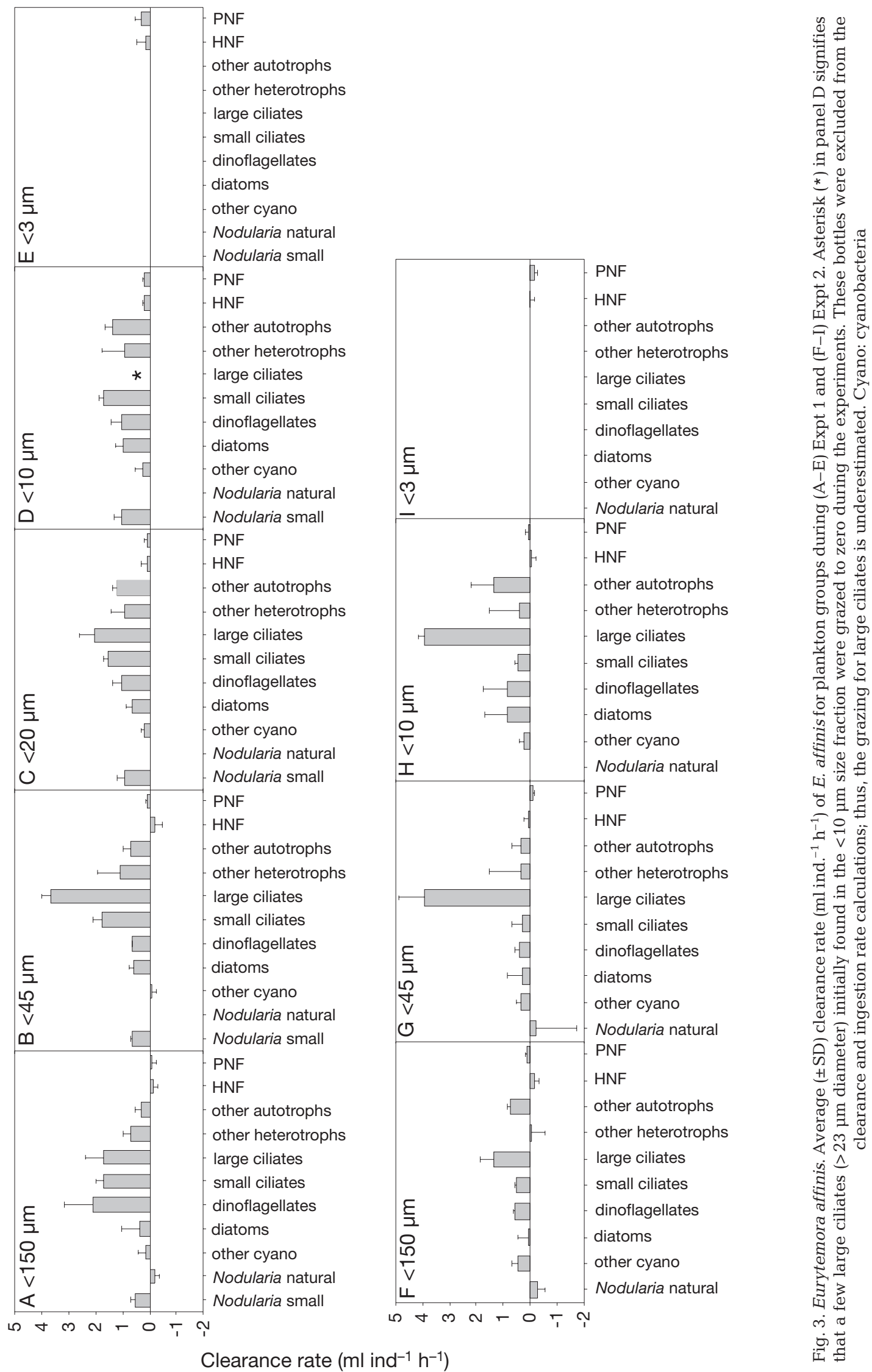




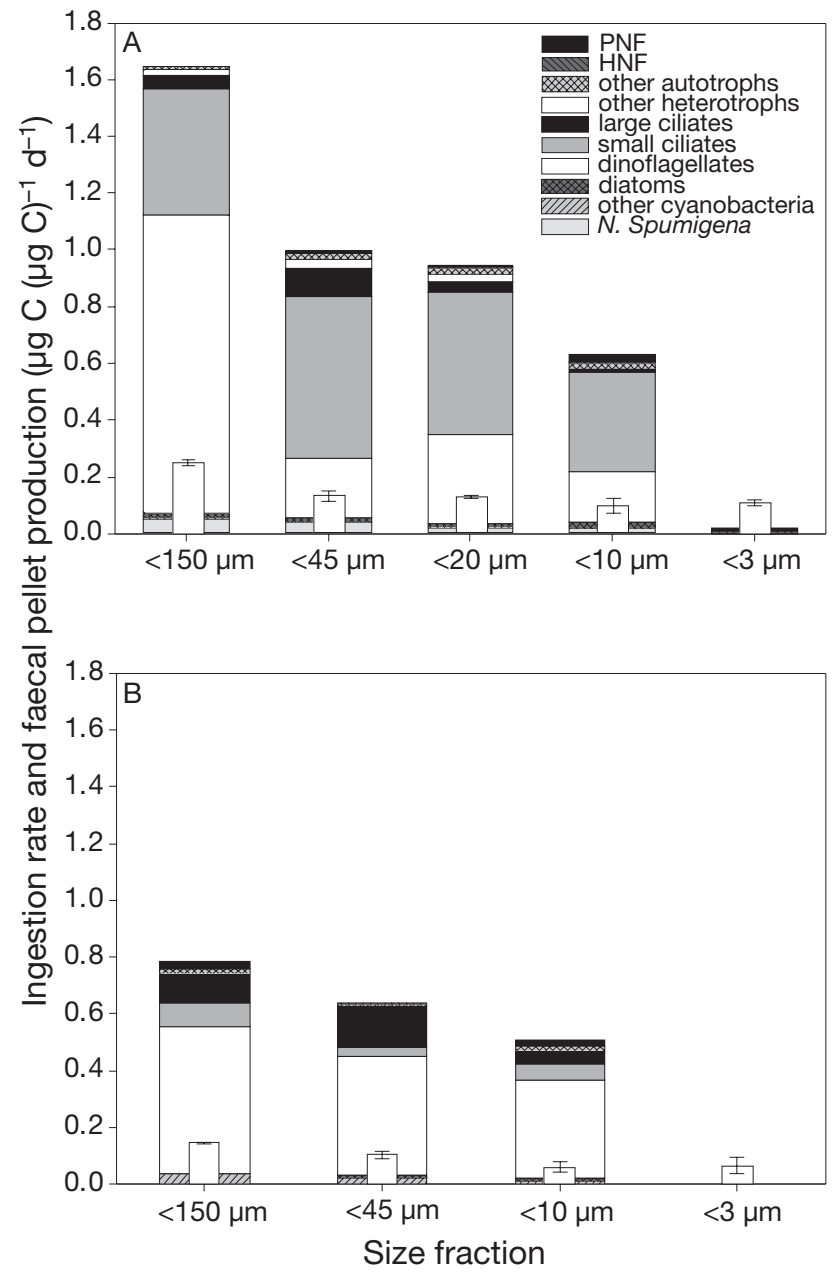

Fig. 4. Eurytemora affinis. Average weight-specific ingestion rate of $E$. affinis feeding on different plankton groups during (A) Expt 1 and (B) Expt 2. Average $( \pm \mathrm{SD})$ weight-specific faecal pellet production of $E$. affinis is represented by superimposed open bars

the experiments. Copepods obtained part of the nodularin by grazing directly on small filaments of cultured Nodularia spumigena in the $<150,<45,<20$ and $<10 \mu \mathrm{m}$ fractions. The clearance rate ranged from $0.6 \pm$ 0.1 to $1.0 \pm 0.3 \mathrm{ml} \mathrm{h}^{-1}$ and weight-specific ingestion ranged from $0.018 \pm 0.004$ to $0.048 \pm 0.008 \mu \mathrm{g} \mathrm{C}(\mu \mathrm{g}$ C) $)^{-1} \mathrm{~d}^{-1}$ (Figs. 3A-E \& 4A). The small N. spumigena filaments were grazed in the same proportion in which they were available without significant preference or avoidance (Dunnett's test, $\mathrm{p}>0.05$ ). The ingestion of small N. spumigena accounted for $39 \%$ of nodularin found in the copepods $\left(\mathrm{r}^{2}=0.39, \mathrm{p}<0.05\right)$. The copepods avoided large filaments of natural $N$. spumigena and the clearance and ingestion rates were negative in both experiments (Fig. 3).

Ciliates and dinoflagellates seemed to be important food sources for the copepods. In the $<150 \mu \mathrm{m}$ fraction, the clearance rates of Eurytemora affinis on dinoflagel- lates, small ciliates $(<23 \mu \mathrm{m})$ and large ciliates (>23 $\mu \mathrm{m})$ were the highest (Kruskal-Wallis ANOVA, $H_{9}=26.7, \mathrm{p}<0.05$ ) (Fig. 3A). Also in the $<45$ and $<20 \mu \mathrm{m}$ fractions, large and small ciliates were grazed at higher clearance rates than in other fractions $\left(<45 \mu \mathrm{m}\right.$ : ANOVA, $F_{8,26}=70.5, \mathrm{p}<0.001 ;<20 \mu \mathrm{m}: F_{9,29}$ $=9.3, \mathrm{p}<0.001$ ) (Fig. 3B,C). In the $<10 \mu \mathrm{m}$ fraction, all of the few large ciliates were completely grazed during the $24 \mathrm{~h}$ incubation and we were not able to estimate the clearance rates. However, in this fraction, the clearance rate of dinoflagellates and small ciliates was significantly higher compared with other organisms (ANOVA, $F_{8,30}=11.8, \mathrm{p}<0.001$ ) (Fig. 3D). For example, $\mathrm{HNF}$ and PNF as food sources for copepods were insignificant with clearance rates ranging from $0.07 \pm$ 0.3 to $0.3 \pm 0.2 \mathrm{ml} \mathrm{h}^{-1}$ in the $<20,<10$ and $<3 \mu \mathrm{m}$ fractions (Fig. 3C-E). The grazing rates on flagellates in both experiments should be considered as the minimum estimates as we did not correct our data to take into account the trophic cascade effects.

As indicated by the clearance rates, the copepods selected dinoflagellates, small ciliates, large ciliates and the 'other heterotrophs' (Oocystis spp., Eutreptiella sp., Planktonema lauterbornii, Cryptomonas spp.) in the $<150,<45,<20$ and $<10 \mu \mathrm{m}$ fractions (Dunnett's test, $\mathrm{p}<0.05$ compared with $\alpha$, for all food groups in all fractions). Grazing on dinoflagellates explained $47 \%$ of the variance in the copepod nodularin content $\left(\mathrm{r}^{2}=0.47, \mathrm{p}=0.01\right)$.

In the $<150 \mu \mathrm{m}$ fraction, the total weight-specific ingestion was $1.6 \mu \mathrm{g} \mathrm{C}(\mu \mathrm{g} \mathrm{C})^{-1} \mathrm{~d}^{-1}$ (Fig. 4A), with dinoflagellates and small ciliates being the most important carbon sources, covering 64 and $27 \%$ of the ingested carbon, respectively (Fig. 4A). Although the large ciliates were selected, they were not an important carbon source due to their relatively low cell density. In the $<45$ and $<20 \mu \mathrm{m}$ fractions, the total ingestion was 0.98 and $0.94 \mu \mathrm{g} \mathrm{C}(\mu \mathrm{g} \mathrm{C})^{-1} \mathrm{~d}^{-1}$, respectively, and in the $<10 \mu \mathrm{m}$ fraction was ca. $30 \%$ less $(0.63 \mu \mathrm{g} \mathrm{C}$ $[\mu \mathrm{g} \mathrm{C}]^{-1} \mathrm{~d}^{-1}$ ). In these fractions, the copepod diet was dominated by small ciliates that formed up to $57 \%$ of ingested carbon. Dinoflagellates were the second most important carbon source covering up to $33 \%$ of total ingestion (Fig. 4A). In the $<3 \mu \mathrm{m}$ fraction, the weightspecific ingestion was only $0.003 \mu \mathrm{g} \mathrm{C}(\mu \mathrm{g} \mathrm{C})^{-1} \mathrm{~d}^{-1}$.

\section{Expt 2}

As in Expt 1, ciliates turned out to be an important food source for copepods in this experiment. Clearance rate on large ciliates was highest in the $<150,<45$ and $<10 \mu \mathrm{m}$ fractions $(<150 \mu \mathrm{m}$ : Kruskal-Wallis ANOVA, $H_{9}=22.1, \mathrm{p}<0.05 ;<45 \mu \mathrm{m}$ : not significant; $<10 \mu \mathrm{m}$ : ANOVA, $F_{9,28}=7.3, \mathrm{p}<0.001$ ) (Fig. $\left.3 \mathrm{~F}-\mathrm{H}\right)$. Eurytemora 


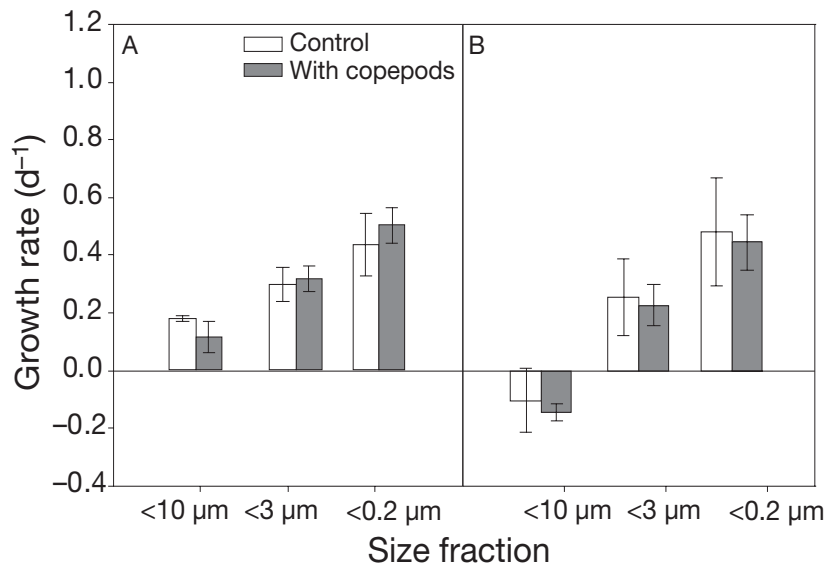

Fig. 5. Average $( \pm \mathrm{SD})$ bacterial growth rate in different size fractions in (A) Expt 1 and (B) Expt 2. Other details are as in Fig. 2

affinis was selecting for large ciliates in the $<150$ and $<45 \mu \mathrm{m}$ fractions (Dunnett's test, $\mathrm{p}<0.05$ compared with $\alpha$ ). The clearance rates on HNF and PNF were low or negative in all size fractions (Fig. $3 \mathrm{~F}-\mathrm{I}$ ).

Total weight-specific ingestion in this experiment was half of that in Expt 1. The copepods ingested 0.79, 0.64 and $0.51 \mu \mathrm{g} \mathrm{C}(\mu \mathrm{g} \mathrm{C})^{-1} \mathrm{~d}^{-1}$ in the $<150,<45$ and $<10 \mu \mathrm{m}$ fractions, respectively (Fig. 4B). Although not actually preferred as food, dinoflagellates were the most important carbon source in these fractions due to their high biomass, contributing 65 to $69 \%$ to the total carbon uptake of the copepods. Large and small ciliates together corresponded to ca. $23 \%$ of total ingestion in these fractions (Fig. 4B). In the $<3 \mu \mathrm{m}$ fraction, the ingestion rates were negative for both $\mathrm{PNF}$ and HNF.

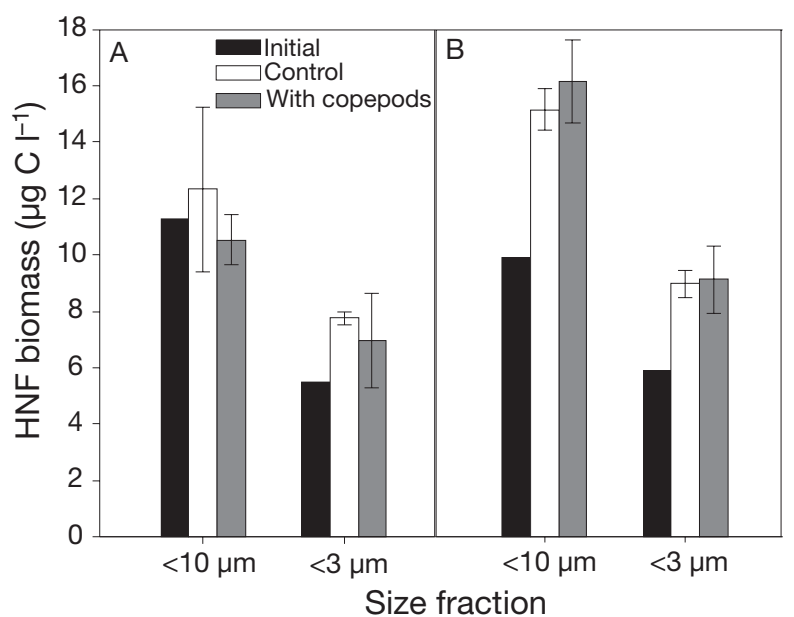

Fig. 6. Average $( \pm \mathrm{SD})$ heterotrophic nanoflagellate $(\mathrm{HNF})$ biomass $\left(\mu \mathrm{g} \mathrm{Cl}^{-1}\right)$ in different size fractions in (A) Expt 1 and (B) Expt 2. Other details are as in Fig. 1

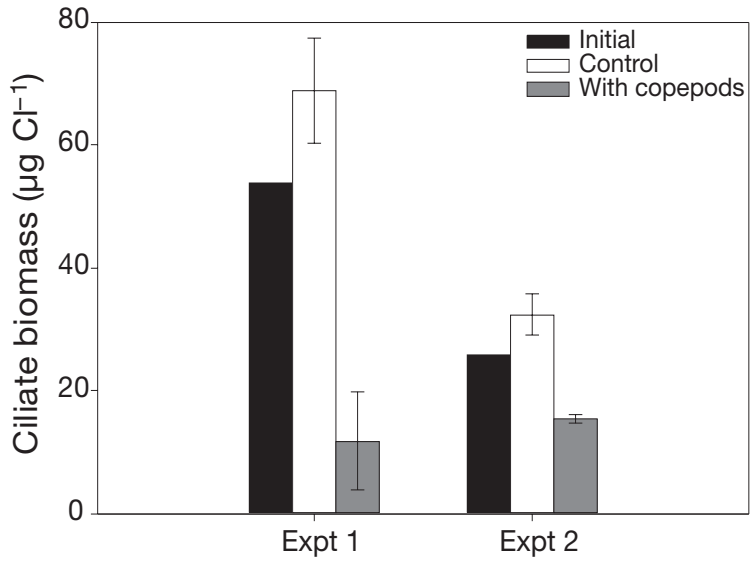

Fig. 7. Average $( \pm \mathrm{SD})$ ciliate biomass $\left(\mu \mathrm{g} \mathrm{C}^{-1}\right)$ in the $<10 \mu \mathrm{m}$ size fraction in Expts 1 and 2. Other details are as in Fig. 1

\section{Egestion}

The weight-specific faecal pellet production by Eurytemora affinis reflected ingestion in both experiments, being ca. $15 \pm 2 \%$ of the total ingestion, (Fig. 4, open bars). However, in the $<3 \mu \mathrm{m}$ size fractions, the pellet production was ca. 20 to $100 \%$ higher than the actual ingestion rate indicated. In the $<0.2 \mu \mathrm{m}$ fractions, the weight-specific pellet production was low, ranging between 0.009 and $0.006 \mu \mathrm{g} \mathrm{C}(\mu \mathrm{g} \mathrm{C})^{-1} \mathrm{~d}^{-1}$ in Expt 1 and Expt 2.

\section{Microbial food web responses}

Grazing on bacteria by HNF and small bacterivore ciliates was evident in the $<10,<3$ and $<0.2 \mu \mathrm{m}$ size fractions. The differences in bacterial growth rates in the $<0.2 \mu \mathrm{m}$ (no grazers) and $<3 \mu \mathrm{m}$ (small HNF) size fractions $\left(0.5\right.$ and $0.3 \mathrm{~d}^{-1}$ in Expt $1,0.5$ and $0.2 \mathrm{~d}^{-1}$ in Expt 2; Fig. 5) indicated the effect of HNF grazing on bacteria in the $<3 \mu \mathrm{m}$ fraction. In the $<10 \mu \mathrm{m}$ fraction, the bacterial growth rates were even lower $\left(0.15 \mathrm{~d}^{-1}\right.$ in Expt 1, $-0.13 \mathrm{~d}^{-1}$ in Expt 2) due to additional grazing by small bacterivore ciliates in both experiments (Fig. 5). The biomass of HNF increased in both experiments without significant differences between replicates with copepods and controls (Fig. 6), indicating that the top-down regulation by copepods through heavy grazing on ciliates (Fig. 7) was reflected only weakly on HNF. While the small size fractions show clearly the bacterial-HNF relationships in the food web, the increased number of functional groups and trophic levels in the larger size fractions increases the complexity of the food web, making the results less obvious. 


\section{Role of the microbial food web in nodularin transfer}

To estimate the relative importance of the microbial food web in nodularin transfer, we compared the average amount of nodularin in copepods from the dissolved size fraction $(<0.2 \mu \mathrm{m})$ with those from the other size fractions. Nodularin found in the copepods from the $<0.2 \mu \mathrm{m}$ fraction corresponded to $16 \pm 7 \%$ and $24 \pm$ $3 \%$ of nodularin found in the copepods from the $<150 \mu \mathrm{m}$ fraction in Expt 1 and Expt 2, respectively. In the $<10,<20$ and $<45 \mu \mathrm{m}$ fractions, this proportion was between $28 \pm 15 \%$ and $39 \pm 13 \%$ for Expt 1 and Expt 2, respectively. In Expt 1, grazing on Nodularia spumigena filaments accounted for $39 \%$ of variation in nodularin content (estimated from the linear regression between $N$. spumigena grazing and nodularin content of the copepods), but in contrast we could not verify any importance of this route in Expt 2. Combining these results gives us a rough estimate of 22 to $45 \%$ $(100 \%$ - the share of direct grazing - the share of the $<0.2 \mu \mathrm{m}$ fraction) obtained from the microbial food web during Expt 1, and 71 to $76 \%$ (100\% - the share of the $<0.2 \mu \mathrm{m}$ fraction) during Expt 2.

\section{DISCUSSION}

\section{Initial conditions}

Our plankton communities were grown in mesocosms which were initiated with natural water samples, and thus they represented a natural variety of plankton organisms present in the Baltic Sea. The biomass of Nodularia spumigena at the beginning of Expt 1 ( $27 \mu \mathrm{g} \mathrm{Cl}^{-1}, 0.25 \mathrm{mg}$ wet wt $\mathrm{l}^{-1}$ ) was in the range of average $N$. spumigena bloom biomasses (0.08 to $0.28 \mathrm{mg}$ wet wt $\mathrm{l}^{-1}$ ) in the Gulf of Finland, Baltic Sea (Kanoshina et al. 2003). The biomass during Expt 2 (109 $\mu \mathrm{g} \mathrm{C} \mathrm{l}^{-1}, 0.99 \mathrm{mg}$ wet wt $\mathrm{l}^{-1}$ ) fits within the range of maximum values (0.23 to $2.91 \mathrm{mg}$ wet wt $\mathrm{l}^{-1}$ ) recorded in the same area (Kanoshina et al. 2003). The initial nodularin concentrations (387 and $199 \mathrm{ng} \mathrm{l}^{-1}$ ) were within the range of natural concentrations found in the Baltic Sea (80 to $18700 \mathrm{ng} \mathrm{l}^{-1}$ ) (Kononen et al. 1993).

\section{Nodularin in the copepods}

At the end of both experiments, nodularin was found in the copepods in all plankton size fractions. In the $<150 \mu \mathrm{m}$ fraction, which corresponds to the total community, copepods contained nodularin concentrations of $14.3 \pm 11.6$ and $6.6 \pm 0.7 \mathrm{pg}$ ind $^{-1}$ in Expt 1 and Expt 2, respectively. Nodularin content of the copepods reflected the initial particulate nodularin concentrations, which were ca. 2.2-fold higher in Expt 1 compared with Expt 2. Because the copepods were grown in the laboratory with no previous contact to nodularin, we can be sure that all the measured nodularin was taken up during the experiments. Kozlowsky-Suzuki et al. (2003) found 1 to 8 pg nodularin ind. $^{-1}$ (using protein phosphatase 1 [PP1] inhibition assay and ELISA) in field-collected copepods that were incubated in the presence of a natural plankton community or in filtered seawater. In contrast, fieldcollected copepods that were incubated with toxic Nodularia spumigena contained nodularin concentrations up to $34 \mathrm{pg}$ ind. $^{-1}$ (Kozlowsky-Suzuki et al. 2003). Lehtiniemi et al. (2002) found nodularin concentrations of $3.2 \mathrm{pg}$ ind. $^{-1}$ (using ELISA) or $9.5 \mathrm{pg}$ ind. $^{-1}$ (using PP1 inhibition assay) in field-collected Eurytemora affinis. These comparisons of nodularin content of the Baltic Sea copepods may not be accurate, since previously published zooplankton toxin measurements in the Baltic Sea have been done with different methods: a PP1 inhibition assay or ELISA (e.g. Lehtiniemi et al. 2002, Kozlowsky-Suzuki et al. 2003). Results of these analyses may be affected by closely related compounds, colour or turbidity (Sipiä et al. 2001). We used the HPLC-MS method, which is selective and sensitive to nodularin (Dahlmann et al. 2001). However, despite different methods used, those results are in the same range as our findings.

In the present study, nodularin that was found in the copepods after the experiments corresponded to a small proportion of initial particulate and dissolved nodularin in the mesocosms. This finding is in accordance with Kozlowsky-Suzuki et al. (2003), who reported that an estimated $0.1 \%$ of ingested nodularin was found in copepod tissues. To estimate the relative importance of copepods as a vector in nodularin transfer to higher trophic levels, we made a rough calculation of the maximum potential of nodularin transfer through copepods to the pelagic mysid Mysis mixta. During August these mysids feed mainly on copepods (40 $\mu \mathrm{g} \mathrm{C} \mathrm{h}$, ca. 17 copepods $\mathrm{h}^{-1}$ ) (Viherluoto \& Viitasalo 2001). The copepods in our $<150 \mu \mathrm{m}$ sizefraction contained 14.3 and $6.6 \mathrm{pg}$ nodularin ind ${ }^{-1}$ in Expt 1 and Expt 2, respectively. By combining these results and the ingestion rates of $M$. mixta, we estimated that mysids may gain nodularin at 2.8 to $5.9 \mathrm{ng}$ ind. ${ }^{-1} \mathrm{~d}^{-1}$. In reality, however, there are loss factors and our estimates were ca. 7- to 15-fold higher than those reported by Karjalainen et al. (2005) for Neomysis integer. These studies suggest that despite the fact that the proportion of nodularin found in the copepods appears low, the potential for acting as a link to planktivorous organisms like mysids and fish is considerable (Karjalainen et al. 2003, 2005, present study). 
The copepods obtained different amounts of nodularin when incubated in different plankton size fractions (Table 4). A large difference was found between the $<150$ and $<45 \mu \mathrm{m}$ fractions; copepods acquired 2.6-fold and 1.2-fold more nodularin in the $<150 \mu \mathrm{m}$ fraction than in the $<45 \mu \mathrm{m}$ fraction in Expt 1 and Expt 2, respectively. The other large differences were seen between the $<10$ and $<3 \mu \mathrm{m}$ fractions in Expt 1 (3.8-fold more nodularin in the $<10 \mu \mathrm{m}$ fraction), and between the $<3$ and $<0.2 \mu \mathrm{m}$ fractions in Expt 2 (2.3-fold more nodularin in $<3 \mu \mathrm{m}$ fraction). To analyse the pathway of nodularin to the copepods, we examined (1) grazing on Nodularia spumigena filaments, (2) nodularin obtained directly from the water in dissolved form, and (3) nodularin obtained by grazing on other planktonic organisms that obtained nodularin directly from the water or through grazing.

\section{Potential nodularin sources}

\section{Nodularia spumigena filaments}

Although the copepod Eurytemora affinis is a suspension feeder, which creates a feeding current to catch its prey, it is able to reject unpleasant food particles and thereby to a large extent chooses its food. Results from our grazing experiments show that $E$. affinis avoided grazing on large natural filaments of $N$. spumigena. On the other hand, E. affinis gained nodularin through direct grazing on small N. spumigena in Expt 1, which led to the large difference in nodularin content in the copepods between $<150$ and $<45 \mu \mathrm{m}$ size fractions. Nodularin transfer due to direct grazing on $N$. spumigena filaments is probably smaller under natural bloom conditions than our experiments suggest, because copepods clearly preferred cultured small filaments over natural N. spumigena. Earlier studies have shown that $E$. affinis is able to feed on toxic N. spumigena, but grazing on it has negative effects on egg production and hatching rates, probably due to the low nutritional quality (Koski et al. 1999, Kozlowsky-Suzuki et al. 2003). Intense blooms also decrease the filtration rates of E. affinis (Sellner et al. 1994). However, a diverse diet sustains better condition of zooplankton and diminishes the negative effects, and if other food is available, toxic algae are ingested in relatively smaller proportions than when provided solely (Reinikainen et al. 1994). Grazing on the small $N$. spumigena filaments correlated with the amount of nodularin found in the copepods in Expt 1. However, the correlation was not strong enough $\left(\mathrm{r}^{2}=\right.$ $0.39, \mathrm{p}<0.05)$ to exclude other pathways to the animals.
Dissolved nodularin

Because particulate nodularin was not found in the $<3$ or $<0.2 \mu \mathrm{m}$ fractions, it may have been present in dissolved form or partly bound to the bacterial biomass in low concentrations, below the detection limit of the nodularin analysis. The initial concentrations of dissolved nodularin were 111 and $42 \mathrm{ng} \mathrm{l}^{-1}$ in the $<3$ and $<0.2 \mu \mathrm{m}$ fractions, respectively. The copepods in the $<0.2 \mu \mathrm{m}$ fraction contained nodularin levels of 12 and $24 \%\left(1.7 \pm 3.8\right.$ and $1.6 \pm 3.5 \mathrm{pg}$ ind.$\left.^{-1}\right)$ in relation to $<150 \mu \mathrm{m}$ fraction after the incubation in Expt 1 and Expt 2, respectively. In a previous study, Karjalainen et al. (2003) incubated Eurytemora affinis in labelled dissolved nodularin with a 45- to 120-fold higher initial concentration $\left(5 \mu \mathrm{g} \mathrm{l}^{-1}\right)$ than that in our study, after which those copepods contained nodularin at $1.8 \pm 0.5 \mathrm{pg}$ ind. ${ }^{-1}$. The initial dissolved nodularin concentration was significantly higher than in our experiments, but nodularin concentration found in the copepods was similar to our results. The possibility that copepods obtain nodularin directly from the water has to be taken into account when discussing the possible routes in nodularin accumulation. Nodularin is a hydrophobic compound that is known to easily attach to surfaces (Hyenstrand et al. 2001). Therefore, it is possible that some of the toxin may be adsorbed onto the surfaces of the copepods instead of being incorporated in the tissues. If so, the toxin would not interfere with the metabolism of the copepods and degradation of the toxin would not occur in its tissues. Copepods with adsorbed nodularin would however act as a vector to higher trophic levels, just like those with nodularin incorporated in the tissues.

\section{The microbial food web}

The copepods obtained roughly 2 to 3 times as much nodularin in the $<45,<20$ and $<10 \mu \mathrm{m}$ fractions compared with the $<0.2 \mu \mathrm{m}$ fraction (Table 4 ). This indicates that nodularin was transferred from other planktonic organisms to the copepods. The results from Expt 2 are especially interesting in this comparison because these fractions did not contain any Nodularia spumigena filaments, whereas in Expt 1 part of the nodularin was clearly obtained via grazing directly on the filaments of small $N$. spumigena (as explained above). The experiments differed especially with respect to the $<3 \mu \mathrm{m}$ fraction; in Expt 1, the copepods obtained nodularin in this fraction as much as from the $<0.2 \mu \mathrm{m}$ fraction, whereas in Expt 2, they obtained as much nodularin from the $<3 \mu \mathrm{m}$ fraction as from the $<10 \mu \mathrm{m}$ fraction. 
The production of faecal pellets indicated that the copepods were feeding actively in all other plankton size fractions except the $<0.2 \mu \mathrm{m}$ fraction, which contained only a few bacteria. The pellet production in the $<3 \mu \mathrm{m}$ fractions was at the same level as in the $<10 \mu \mathrm{m}$ fractions in both experiments although the calculated ingestion rates were low in Expt 1 and negative in Expt 2, indicating that nanoflagellates were not the vector of nodularin to copepods. On the other hand, it is possible that the high growth capacity of nanoflagellates masked the low grazing by copepods on these organisms. Also, Uitto (1996) concluded that mesozooplankton could not control nanoprotozoan biomass because they are able to remove only 2 to $6 \%$ of the biomass of nanoprotozoans per day.

Eurytemora affinis had clear preferences for its prey. It grazed efficiently on ciliates and dinoflagellates, and the ingested carbon originated mainly from these organisms in both experiments. Similarly, Merrell \& Stoecker (1998) reported that E. affinis obtained 25 to $60 \%$ of its daily carbon by feeding on ciliates, and it grazed on the dinoflagellate Prorocentrum minimum with the same clearance rates as that for E. affinis grazing on dinoflagellates in our experiments. In the Baltic Sea, natural ciliate cell densities range from less than

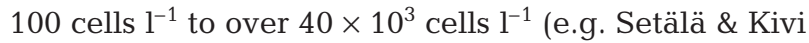
2003). Thus, in the mesocosms, the initial densities of small ciliates $\left(173\right.$ and $153 \times 10^{3}$ cells $\left.1^{-1}\right)$ were relatively high, whereas large ciliates ( 4 and $17 \times 10^{3}$ cells $\mathrm{l}^{-1}$ ) were present in the range they are found in natural settings. Due to the presence of ciliates, the diet of the copepods was of good quality.

In Expt 2 dinoflagellates were an important carbon source in all the fractions, while in Expt 1 ciliates were more important in the $<45,<20$ and $<10 \mu \mathrm{m}$ fractions. Additionally, a large difference in the nodularin content of the copepods was observed between the $<3$ and $<10 \mu \mathrm{m}$ fractions in Expt 1. These results are important, knowing that ciliates may graze on lower trophic levels, but also because these organisms, in turn, are able to take up nodularin straight from the dissolved form (Karjalainen et al. 2003).

Ciliates are known to be important grazers of nanoplankton populations in the sea (e.g. Verity 1986, Kuuppo-Leinikki et al. 1994) and some ciliates have shown high selectivity in choosing their food items (Stoecker et al. 1981). In our study, the relief from ciliate grazing pressure did not reflect clearly in the growth rates of nanoplanktonic communities in our size fractions. In our experiments, the majority of the ciliates were small (10 to $20 \mu \mathrm{m})$, and the community was composed of choreotrichs (e.g. Strobilidium sp.) and haptorids (e.g. Mesodinium pulex, Ascenasia sp., Myrionecta rubra), which are able to ingest bacteria (Kisand \& Zingel 2000, Myung et al. 2006). The lack of a visible effect in the flagellate communities may be due to scarcity of those ciliate grazers which prefer food in the size range of ca. 2 to $10 \mu \mathrm{m}$ (Kivi \& Setälä 1995). Furthermore, the previously mentioned trophic cascade effects due to the presence of several functional groups may have complicated the results in our larger size fractions. Heterotrophic nanoflagellates consume bacteria and are important in controlling their abundance and community structure (KuuppoLeinikki 1990). In accordance with this fact, the growth rates of bacteria were strongly influenced by the presence of HNF in our experiments.

Grazing on dinoflagellates correlated significantly with the concentrations of nodularin found in the copepods in Expt $1\left(\mathrm{r}^{2}=0.47, \mathrm{p}=0.01\right)$. Recent studies reveal that increasingly more dinoflagellate species are mixotrophic and have the ability to utilise organic matter for their growth (reviewed by Hansen 1998). Thus, nodularin transfer via dinoflagellate mixotrophy cannot be excluded in our results, but instead raises questions for future studies.

The compartments of the microbial loop were in tight interaction, and we could follow the top-down control of the lower trophic levels during our experiments. In the size fractions smaller than the $<150 \mu \mathrm{m}$ fraction, the presence of copepods affected the amount of nodularin found in the particulate form. However, at the end of the experiments, the copepods contained less nodularin than what had been lost. Bacteria may be partly responsible for that difference, because they degrade nodularin in both particulate and dissolved forms (Hagström 2006). In addition, part of the ingested nodularin was probably effectively metabolized by the copepods (Karjalainen et al. 2006). Copepods originating from areas with Nodularia spumigena blooms might have the ability to combat the negative effects of the toxin (Kozlowsky-Suzuki et al. 2003) and might have effective mechanisms to remove these compounds from their tissues (Sipiä et al. 2002).

We were not able to study the explicit mechanism by which the nodularin actually was transferred between different compartments in the food web. Nodularin attaches easily on all kinds of surfaces (Hyenstrand et al. 2001). The lower dissolved nodularin concentrations in our $<3$ and $<150 \mu \mathrm{m}$ fractions compared with the $<0.2 \mu \mathrm{m}$ fraction support that idea. Hence, dinoflagellates as well as other planktonic organisms in our study may carry nodularin on their cell surfaces leading to a significant correlation, for example, between dinoflagellate grazing and nodularin content in copepods.

In our experiments, nodularin was transferred to the copepods through all 3 potential pathways: (1) grazing on filaments of small Nodularia spumigena, (2) 
directly from the dissolved pool, and (3) through the microbial food web by copepod grazing on ciliates, dinoflagellates and HNF. The estimated proportion of toxin transfer through the microbial food web was 22 to $45 \%$ and 71 to $76 \%$ in Expts 1 and 2, respectively. This highlights the possible role of the microbial food web in the transfer of HAB toxins in aquatic ecosystems.

\section{HABs and the microbial food web}

Harmful algae have strong effects in the ecosystem. Cyanobacterial blooms are often associated with relative changes in grazer community. These changes may be due to predation by zooplanktivores (reviewed by Turner \& Granéli 2006), interference with feeding because of the bad manageability of filaments or colonies, chemical factors (e.g. toxicity, low nutritional value) or high abundances (i. e. blooms) that limit the ability of grazers to feed on other coexisting algae. The bacterial communities are also affected by the cyanobacterial blooms (Doucette et al. 1998). These alterations can change the carbon flow in the food web and restructure the plankton community. However, although direct effects of toxins have been studied and toxins are known to be transferred at all levels of the aquatic food web (Turner \& Granéli 2006), relatively little is known about the importance of the microbial food web in toxin transfer in general and in nodularin transfer in particular. Although the chemical structure varies among toxins, and this leads to high differences in toxicity (Sivonen \& Jones 1999), toxin groups such as nodularins and microcystins have similar ways to affect aquatic and terrestrial organisms - for example, by entering the hepatocytes in the liver. As a result of their stable molecular composition, these toxins are transferred further into the food web. These similarities suggest common mechanisms of toxin transfer that involve the microbial loop as well. Thus, the importance of trophic cascades in the transfer of cyanobacterial toxins should also be studied in freshwater environments.

Acknowledgements. We thank the University of Kalmar, Sweden, for providing excellent facilities for the experiments. O. Setälä gave valuable advice concerning ciliate identification and ecology. We also thank 3 anonymous reviewers for their helpful comments, which significantly improved the manuscript. This work was partly funded by the European Commission through the FATE project 'Transfer and Fate of Harmful Algal Bloom (HAB) Toxins in European Marine Waters' (EVK3-CT2001-00055) as part of the EC-EUROHAB cluster, and partly by the Maj and Tor Nessling Foundation, Finland. S.S. was funded by the Walter and Andrée de Nottbeck Foundation, Finland.

\section{LITERATURE CITED}

Azam F, Fenchel T, Field JG, Gray JS, Meyer-Reil LA, Thingstad F (1983) The ecological role of water-column microbes in the sea. Mar Ecol Prog Ser 10:257-263

Bjørnsen PK (1986) Automatic determination of bacterioplankton biomass by image analysis. Appl Environ Microbiol 51:1199-1204

Børsheim KY, Bratbak G (1987) Cell volume to cell carbon conversion factors for a bacterivorous Monas sp. enriched from seawater. Mar Ecol Prog Ser 36:171-175

- Chesson J (1983) The estimation and analysis of preference and its relationship to foraging models. Ecology 64: $1297-1304$

> Dahlmann J, Rühl A, Hummert C, Liebezeit G, Carlsson P, Granéli E (2001) Different methods for toxin analysis in the cyanobacterium Nodularia spumigena (Cyanophyceae). Toxicon 39:1183-1190

Dahlmann J, Budakowski WR, Luckas B (2003) Liquid chromatography-electrospray ionisation-mass spectrometry based method for the simultaneous determination of algal and cyanobacterial toxins in phytoplankton in marine waters and lakes followed by tentative structural elucidation of microcystins. J Chromatogr A 994:45-57

Doucette GJ, Kodama M, Franca S, Gallacher S (1998) Bacterial interactions with harmful algal bloom species: bloom ecology, toxigenesis, and cytology. In: Anderson DM, Cembella AD, Hallegraeff GM (eds) Physiological ecology of harmful algal blooms. NATO ASI Series, Vol G 41. Springer-Verlag, Berlin, p 619-648

Edler L (ed) (1979) Recommendations on methods for marine biological studies in the Baltic Sea. Phytoplankton and chlorophyll. Baltic Marine Biologists Working Group 9, Lund

Engström-Öst J, Koski M, Schmidt K, Viitasalo M and others (2002a) Effects of toxic cyanobacteria on a plankton assemblage: community development during decay of Nodularia spumigena. Mar Ecol Prog Ser 232:1-14

> Engström-Öst J, Lehtiniemi M, Green S, Kozlowsky-Suzuki B, Viitasalo M (2002b) Does cyanobacterial toxin accumulate in mysid shrimps and fish via copepods? J Exp Mar Biol Ecol 276:95-107

Frost BW (1972) Effects of size and concentration of food particles on the feeding behavior of the marine planktonic copepod Calanus pacificus. Limnol Oceanogr 17:805-815

González HE, González SR, Brummer GJA (1994) Short term sedimentation pattern of zooplankton, faeces and microplankton at a permanent station in the Bjornafjorden (Norway) during April-May 1992. Mar Ecol Prog Ser 105:31-45

Guillard RR, Ryther JH (1962) Studies of marine planktonic diatoms. I. Cyclotella nana Hustedt, and Detonula confervacea Cleve. Can J Microbiol 8:229-239

Hagström J (2006) Fate of marine algal toxins in presence of bacteria and mussel or copepod faecal matter. PhD dissertation, University of Kalmar

Hansen PJ (1998) Phagotrophic mechanisms and prey selection in mixotrophic phytoflagellates. In: Anderson DM, Cembella AD, Hallegraeff GM (eds) Physiological ecology of harmful algal blooms. NATO ASI Series, Vol G 41. Springer-Verlag, Berlin, p 525-537

- Hyenstrand P, Metcalf JS, Beattie KA, Codd GA (2001) Losses of the cyanobacterial toxin microcystin-LR from aqueous solution by adsorption during laboratory manipulations. Toxicon 39:589-594

Kahru M, Horstmann U, Rud O (1994) Satellite detection of increased cyanobacteria blooms in the Baltic Sea: natural 
fluctuation or ecosystem change? Ambio 23:469-472

Kanoshina I, Lips U, Leppänen JM (2003) The influence of weather conditions (temperature and wind) on cyanobacterial bloom development in the Gulf of Finland (Baltic Sea). Harmful Algae 2:29-41

Karjalainen M, Reinikainen M, Lindvall F, Spoof L, Meriluoto JAO (2003) Uptake and accumulation of dissolved, radiolabelled nodularin in Baltic Sea zooplankton. Environ Toxicol 18:52-60

Karjalainen M, Reinikainen M, Spoof L, Meriluoto J, Sivonen K, Viitasalo M (2005) Trophic transfer of cyanobacterial toxins from zooplankton to planktivores: consequences for pike larvae and mysid shrimps. Environ Toxicol 20: 354-362

Karjalainen M, Kozlowsky-Suzuki B, Lehtiniemi M, EngströmÖst J, Kankaanpää H, Viitasalo M (2006) Nodularin accumulation during cyanobacterial blooms and experimental depuration in zooplankton. Mar Biol 148: 683-691

Kisand V, Zingel P (2000) Dominance of ciliate grazing on bacteria during spring in a shallow eutrophic lake. Aquat Microb Ecol 22:135-142

Kivi K, Setälä O (1995) Simultaneous measurement of food particle selection and clearance rates of planktonic oligotrich ciliates (Ciliophora: Oligotrichina). Mar Ecol Prog Ser 119:125-137

Kononen K, Sivonen K, Lehtimäki J (1993) Toxicity of phytoplankton blooms in the Gulf of Finland and Gulf of Bothnia, Baltic Sea. In: Smayda TJ, Shimizu Y (eds) Toxic phytoplankton blooms in the sea. Elsevier Science, New York, p 269-273

Koski M (1999) Carbon:nitrogen ratios of Baltic Sea copepods-indication of mineral limitation? J Plankton Res 21:1565-1573

Koski M, Engström J, Viitasalo M (1999) Reproduction and survival of the calanoid copepod Eurytemora affinis fed with toxic and non-toxic cyanobacteria. Mar Ecol Prog Ser 186:187-197

Kozlowsky-Suzuki B, Karjalainen M, Lehtiniemi M, Engström-Öst J, Koski M, Carlsson P (2003) Feeding, reproduction and toxin accumulation by the copepods Acartia bifilosa and Eurytemora affinis in the presence of the toxic cyanobacterium Nodularia spumigena. Mar Ecol Prog Ser 249:237-249

Kuosa H, Kivi K (1989) Bacteria and heterotrophic flagellates in the pelagic carbon cycle in the northern Baltic Sea. Mar Ecol Prog Ser 53:93-100

Kuuppo-Leinikki P (1990) Protozoan grazing on planktonic bacteria and its impact on bacterial population. Mar Ecol Prog Ser 63:227-238

Kuuppo-Leinikki P, Kuosa H (1989) Preservation of picoplanktonic cyanobacteria and heterotrophic nanoflagellates for epifluoresence microscopy. Arch Hydrobiol 114:631-636

Kuuppo-Leinikki P, Autio R, Hällfors S, Kuosa H, Kuparinen J, Pajuniemi R (1994) Trophic interactions and carbon flow between picoplankton and protozoa in pelagic enclosures manipulated with nutrients and a top predator. Mar Ecol Prog Ser 107:89-102

Lehtimäki J, Moisander P, Sivonen K, Kononen K (1997) Growth, nitrogen fixation, and nodularin production by two Baltic Sea cyanobacteria. Appl Environ Microbiol 63:1647-1656

Lehtiniemi M, Engström-Öst J, Karjalainen M, KozlowskySuzuki B, Viitasalo M (2002) Fate of cyanobacterial toxins in the pelagic food web: transfer to copepods or to faecal pellets? Mar Ecol Prog Ser 241:13-21

Menden-Deuer S, Lessard EJ (2000) Carbon to volume rela- tionship for dinoflagellates, diatoms, and other protist plankton. Limnol Oceanogr 45:569-579

Merrell JR, Stoecker DK (1998) Differential grazing on protozoan microplankton by developmental stages of the calanoid copepod Eurytemora affinis Poppe. J Plankton Res 20:289-304

> Myung G, Yih W, Kim HS, Park JS, Cho BC (2006) Ingestion of bacterial cells by the marine photosynthetic ciliate Myrionecta rubra. Aquat Microb Ecol 44:175-180

Nishiwaki-Matsushima R, Ohta T, Nishiwaki S, Suganuma M and others (1992) Liver tumour promotion by the cyanobacterial cyclic peptide toxin microcystin-LR. J Cancer Res Clin Oncol 118:420-424

Porter KG, Feig YS (1980) The use of DAPI for identifying and counting aquatic microflora. Limnol Oceanogr 25:943-948

Putt M, Stoecker DK (1989) An experimentally determined carbon:volume ratio for marine 'oligotrichous' ciliates from estuarine and coastal waters. Limnol Oceanogr 34: $1097-1103$

Reinikainen M, Ketola M, Walls M (1994) Effects of the concentration of toxic Microcystis aeruginosa and an alternative food on the survival of Daphnia pulex. Limnol Oceanogr 39:424-432

Sellner KG (1997) Physiology, ecology, and toxic properties of marine cyanobacterial blooms. Limnol Oceanogr 42: 1089-1104

Sellner KG, Olson MM, Kononen K (1994) Copepod grazing in a summer cyanobacteria bloom in the Gulf of Finland. Hydrobiologia 292-293:249-254

Setälä O, Kivi K (2003) Planktonic ciliates in the Baltic Sea in summer: distribution, species association and estimated grazing impact. Aquat Microb Ecol 32:287-297

Sipiä V, Kankaanpää H, Lahti K, Carmichael WW, Meriluoto J (2001) Detection of nodularin in flounders and cod from the Baltic Sea. Environ Toxicol 16:121-126

Sipiä VO, Kankaanpää HT, Pflugmacher S, Flinkman J, Furey A, Jamen KJ (2002) Bioaccumulation and detoxification of nodularin in tissues of flounder (Platichthys flesus), mussels (Mytilus edulis, Dreissena polymorpha), and clams (Macoma balthica) from the northern Baltic Sea. Ecotoxicol Environ Safe 53:305-311

Sipiä V, Kankaanpää H, Peltonen H, Vinni M, Meriluoto J (2007) Transfer of nodularin to three-spined stickleback (Gasterosteus aculeatus L.), herring (Clupea harengus L.), and salmon (Salmo salar L.) in the northern Baltic Sea. Ecotoxicol Environ Safe 66:421-425

Sivonen K, Jones G (1999) Cyanobacterial toxins. In: Chorus I, Bartram J (eds) Toxic cyanobacteria in water: a guide to their public health consequences, monitoring and management. E \& FN Spon, London, p 41-111

Sivonen K, Kononen K, Carmichael WW, Dahlem AM, Rinehart KL, Kiviranta J, Niemelä I (1989) Occurrence of the hepatotoxic cyanobacterium Nodularia spumigena in the Baltic Sea and structure of the toxin. Appl Environ Microbiol 55:1990-1995

Stoecker DK, Guillard RRL, Kavee RM (1981) Selective predation by Favella ehrenbergii (Tintinnia) on and among dinoflagellates. Biol Bull (Woods Hole) 160:136-145

Turley CM (1993) Direct estimates of bacterial numbers in seawater samples without incurring cell loss due to sample storage. In: Kemp PF, Sherr BF, Sherr EB, Cole JJ (eds) Handbook of methods in aquatic microbial ecology. Lewis Publishers, Boca Raton, FL, p 143-147

Turner JT, Granéli E (2006) 'Top-down' predation control on marine harmful algae. In: Granéli E, Turner JT (eds) Ecology of harmful algae. Ecological Studies Vol 189. Springer-Verlag, Berlin, p 355-366 
Uitto A (1996) Contribution of nanoprotists to metazooplankton diet in a mesocosm experiment in the coastal northern Baltic. J Plankton Res 18:2119-2137

Utermöhl H (1958) Vervollkommung der quantitativen Phytoplankton-Methodik. Mitt Internat Ver Limnol 9:1-38

- Verity PG (1986) Grazing of phototrophic nanoplankton by microzooplankton in Narragansett Bay. Mar Ecol Prog Ser 29:105-115

Editorial responsibility: Urania Christaki, Wimereux, France
Viherluoto M, Viitasalo M (2001) Temporal variability in functional responses and prey selectivity of the pelagic mysid, Mysis mixta, in natural prey assemblages. Mar Biol 138:575-583

Yoshizawa S, Matsusima R, Watanabe MF, Harada K, Ichihara A, Carmichael WW, Fujiki H (1990) Inhibition of protein phosphatases by microcystins and nodularin associated with hepatotoxicity. J Cancer Res Clin Oncol 116:609-614

Submitted: September 10, 2008; Accepted: February 15, 2009 Proofs received from author(s): April 7, 2009 